\title{
A BIBLIOMETRIC ANALYSIS OF COHESIVE SPEECH RESEARCH OF PRESCHOOLERS FROM 1970 TO 2020
}

\author{
Ly Thi Bac La \\ Hanoi National University of Education, Vietnam \\ E-mail: lyltb@hnue.edu.vn \\ Nga Thi Thu Nguyen \\ Hanoi Metropolitan University, Vietnam \\ E-mail: nttnga@daihocthudo.edu.vn \\ Anh Thi Thuy Truong \\ Thai Nguyen University of Education, Vietnam \\ E-mail: anhttt@tnue.edu.vn \\ Thu-Giang Tran, The-Thang Nguyen \\ E-mail: giangtt@vnies.edu.vn, thangvcl@gmail.com
}

The Vietnam National Institute of Educational Sciences, Vietnam

\begin{abstract}
Cohesive speech has commonly become regarded as one of the essential aspects of language development, especially for pre-schoolers. This study aimed to shed light on the cohesive speech of pre-schoolers (CSP) knowledge base. Three hundred ninety-five publications close related cohesive speech research of 5-6-year-old children were collected from the Scopus database. By using the bibliometric approach, the results showed the growth rate of publications over time from 1970 to 2020. In this period, the top five countries, the United States, the United Kingdom, Australia, Brazil and France, have published over $60 \%$ of total documents. Besides, four main interests of authors in this field were discovered: "language development", "speech pathology outcomes", "speech therapy", "language intervention". Among these themes, "speech pathology outcomes" was the most relevant one. Another finding, in recent years, scholars focused on aspects of autism spectrum disorder of pre-schoolers. More importantly, the achievements of this discipline have considerably made positive contributions to various fields both in terms of theory and practice, especially in language and linguistics, speech and hearing, psychology, and medicine. Overall, these studies highlight the need for many other studies, particularly relevant to preschooling when new generations should be better prepared to be happy in school by their future cognitive developments.
\end{abstract}

Keywords: language development, language intervention, speech pathology outcomes, speech therapy

\section{Introduction}

Language seemly remains the great innovation of the humans, it is not because how it has changed human beings from primitive societies into civilized that we are living these days, and it is because how erudite of manifold complicated messages we have created and communicated to each other. Therefore, it can possibly be said that language is one the most advanced cultural tools created by people and makes people developed continuously. Especially, this creative 
Ly Thi Bac LA, Nga Thi Thu NGUYEN, Anh Thi Thuy TRUONG, Thu-Giang TRAN, The-Thang NGUYEN. A bibliometric analysis of cohesive speech research of preschoolers from 1970 to 2020

PROBLEMS

OF EDUCATION

IN THE $21^{\text {st }}$ CENTURY Vol. 79, No. 4, 2021

612

tool has many more important roles in the perspectives of linguistics and education because it is agreed by many teachers that a child could not have achieved the best results if he/she had been adroit of coherence in the ways of speech. However, despite being crucially developed and changed, coherence always remains important in expressions in any language. It is essential for effective communication, and it enables people to use languages to give a written or spoken text unity and purpose accurately. More meaningfully, it refers to common sense that a text or message is organized or logical by an understandable structure.

Significance to children development and cognition obtained in schooling or family education, varied authors have researched coherent speech to make this sector more important than ever. Regarding the ways in which the development of coherent speech in schools can be done by Ukrainian students expressing themselves independently and creatively orally, the findings suggest that these skills are often influenced by the contexts and by the students' proficiency in the Ukrainian language. These coherent speech abilities can be improved by the teacher (Trevoho \& Zadorozhnyy, 2020). By the assistance of teachers in school, at senior preschool age and the development of coherent speech depend on what these children are taught in the family, and some principles of organizing speech therapy with specific psychological and pedagogical preparation that could be taken can usefully help pre-schoolers (Egorova, 2020). Besides, the children who are about to go to school need to be prepared to communicate in schooling. However, these speeches should be a contented, consistent, accurate, grammatical, and speaking environment, including friends, adults, and other community interactions. Coherent speech is also regarded as one of the kinds of competencies leading to the success of the children. That is even considered as a complex process in psychology and pedagogy to deal with negative aspects of speech consisting of semantic, lexical, and grammatical errors by illustration-based storytelling, making up riddles and fairy tales, describing personal experience, and etcetera that is named as the Theory of Inventive Problem Solving (Simkin \& Gelikhova, 2019). Another way of making senior pre-schoolers better with their speeches in terms of qualitative characteristics, represented by simple and complex sentences, is Means of Project Activities (Kuznetsova, 2020).

This aspect of language has not been researched in the linguistics areas only, but it has been interested by many researchers of various disciplines, in the healthy domain, such as Homøe et al. (2013), Jones et al. (2005), Lieu et al. (2010), or in the ways of interdisciplinary between education and health, for example, Kingston et al. (2003), Broomfield \& Dodd (2004), Lewis et al. (2006), Lohmander et al. (2012), Wang et al. (2013), Murray et al. (2012), etc. Coherence in speech, even, has been an object of research since 1970, but no previous research has summarized the literature of coherence speech of five or six-year-old-children. Thus, this paper aimed to review the research conducted on coherence speech in all fields published in academically journals and documents, primarily represented in areas relevant to research themes, including children, Cleft palate, Speech therapy, Intervention, Language, and Speech disorder by answering four research questions (RQs) as follows:

RQ1. What are the total publications and geographic distribution of published documents among countries in the CSP knowledge base?

RQ2. What authors have had the greatest relevance in CSP research, and what are they interested in?

RQ3. What documents and topics have had the greatest relevance in the CSP knowledge base?

RQ4. What are the latest topics in recent years in the CSP knowledge base? 
Ly Thi Bac LA, Nga Thi Thu NGUYEN, Anh Thi Thuy TRUONG, Thu-Giang TRAN, The-Thang NGUYEN. A bibliometric analysis of cohesive speech research of preschoolers from 1970 to 2020

\section{Research Methodology}

\section{General Background}

Bibliometrics was adapted to explore the most relevant authors, countries, documents, topics in the coherence speech of five to six-year-old pre-schoolers. This method is able to represent the researchers, journals, countries related to scientific subjects (Marti Parreño et al., 2016; Pham, 2021). Moreover, using science mapping determined the relationships among individual authors and documents (Small, 1999) related to coherence speech between 1970 and 2020 .

\section{Data Collection}

The bibliometrics method, proposed by (Pritchard et al, 1969), is referred to conduct this scholar. This approach is applied to review literature in many fields, including educational research. For example, (Hallinger \& Chatpinyakoop, 2019), based on the bibliometrics method, it shows the intellectual structure of 1,459 Scopus-indexed documents and highlights the main research issues. Moreover, the bibliometrics method was conducted based on meta-data of a dataset (Madani \& Weber, 2016). Thus, Scopus was referred to as a source to collect data. There were two reasons for this choice. Firstly, it is a popular source for the research community of bibliometrics method (Fetscherin \& Heinrich, 2015). Secondly, Scopus's coverage of social sciences is broader than others in the same subject (Harzing \& Alakangas, 2017).

The data were obtained through the extraction from Scopus and the eligibility of all the records. In the first step, the query was searched in the source in which the document information, including title, abstract and keywords, were concerned. All the terms which were used in the search represented the scope of this scholar: coherence issues, preschool, five or six-year-old. The initial search was:

TITLE-ABS-KEY (("Speech therapy" OR "language therapy" OR "language treatment" OR "speech treatment" OR "Coherence speech" OR "Speech coherence" OR "Consistent speech") AND ( preschool OR "5 years old" OR "6 years old" OR "5-6 years old" OR "5 to 6 years old"))

At the time of the search, 24h 14 February 2021, there were 3,179 variable records. To focus on the search gap, the parameters set of criteria was applied within the initial results, including:

Limitation of document type: Article

Limitation of language: English

Limitation of subjects: Medicine, Health professions, Social sciences, Arts and Humanities, Psychology

Exclude of the published year: 2021

After filtering, the number of datasets left 2,280 variable records, which were downloaded into an Excel file and used in the next step.

In the second step, 2,280 records were divided into all the research team members who had to read the title, abstract and full text of each document to check their eligibility. There were 1,885 excluded records whose content did not fit this scholar. For example, Prathanee et al. (2020) showed the model of speech therapy for children under 5-year-old with cleft palate in the Lao People's Democratic Republic. The final dataset had 395 valid records, which was analysed deeply in this paper. 
Ly Thi Bac LA, Nga Thi Thu NGUYEN, Anh Thi Thuy TRUONG, Thu-Giang TRAN, The-Thang NGUYEN. A bibliometric analysis of cohesive speech research of preschoolers from 1970 to 2020

PROBLEMS

OF EDUCATION

IN THE $21^{\text {st }}$ CENTURY

Vol. 79 , No. 4, 2021

614

Data Analysis

The final dataset was transferred to the bibliometric software, including $\mathrm{R}$ statistic software and VOSviewer. To answer the RQs, the bibliometric analyses applied in this scholar were description statistics, coupling analysis, co-authorship analysis, co-occurrence keywords analysis. Description statistics was conducted in $\mathrm{R}$, in which their calculations showed the most relevant authors, journals and countries based on the number of their documents and number of their citations. Moreover, documents coupling analysis was examined to explore the main topics of the knowledge base. Besides, co-authorship analysis and co-occurrence keywords analysis were conducted in VOSviewer. Co-authorship analysis showed the relationship between authors, countries. Co-occurrence keywords analysis demonstrated the frequency of words that appear in the keywords of documents (Zupic \& Čater, 2015).

\section{Research Results}

\section{The Total Publications and Geographic Distribution of Published Documents among} Countries in the CSP Knowledge Base

There were 395 publications of CSP knowledge base in the period between 1970 and 2020. Figure 1 showed the number of published articles over time. Overall, the growth rate of publications for the whole period was $6.92 \%$ per year. The first article in this field was the document of Hamlen (1970). In his document, Hamlen investigated factors that influence the final speech results of four to 19-year-old children after palatopharyngeal flap procedures. Based on the growth rate of publications, three stages were divided. The first stage, namely the formation stage, had $0 \%$ growth rate per year for 24 years from 1970 to 1993 . There were 25 published documents related to the CSP area, approximately $6.32 \%$ in total. The second stage, namely the development stage, had 6.53\% growth rate in 17 years from 1994 to 2010. There were 133 published documents at this time, approximately $33.67 \%$ in total. The third stage, namely the stabilization stage, had $1.24 \%$ growth rate in 10 years from 2011 to 2020. There were 237 published documents in this phase, approximately $60.00 \%$ in total. From these data, it is clear that the first publication was reported 50 years ago; however, this field just had the huge attention of the researcher community ten recent years. Moreover, the results demonstrated the small growth rate of published documents of CSP in the future.

\section{Figure 1}

Number of Documents of CSP Knowledge Base between 1970 and 2020

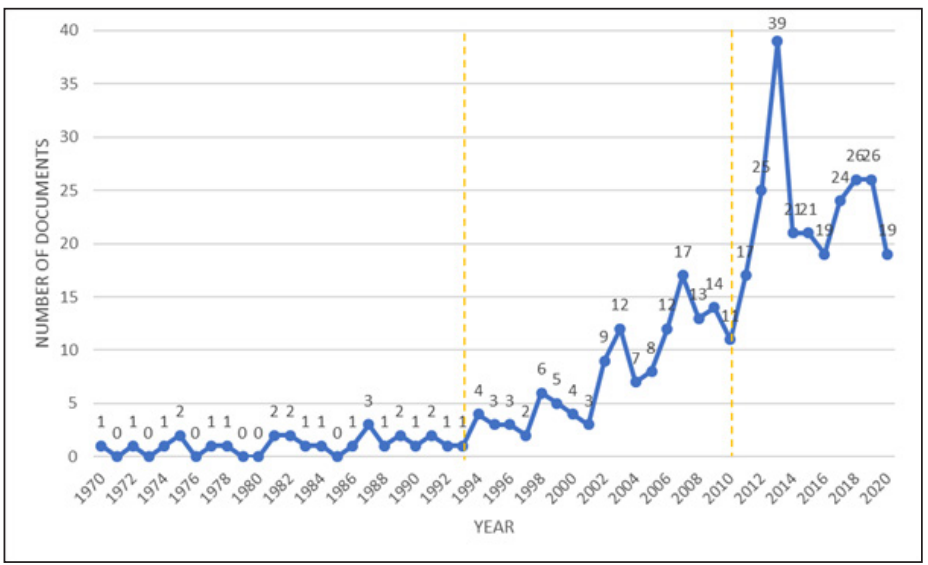


Ly Thi Bac LA, Nga Thi Thu NGUYEN, Anh Thi Thuy TRUONG, Thu-Giang TRAN, The-Thang NGUYEN. A bibliometric analysis of cohesive speech research of preschoolers from 1970 to 2020

Figure 1 represented the collaborations of 42 countries in CSP. Based on the size of nodes, the United States was the lead country of the network (ranking: \#1; number of publications: 136; number of citations: 3,647), following the United Kingdom (\#2; 58; 1,957), Australia (\#3; 38; 946), Brazil (\#4; 28; 128) and France (\#5; 20; 485). These countries published 257 documents, approximately $65.05 \%$ in the total publication of CSP, and they had 7,163 citations, approximately $65.08 \%$ in total citations of CSP. Based on the link strength among countries, the thickest link was the connection between the United States and Australia (nine documents). After that, the link strength between Australia and the United Kingdom was eight. The link strength of the others was lower than five. However, Brazil, a top-five country by the number of documents, did not have any research collaboration with others. It was clear that with the total number of publications, the collaborations among countries in this field were weak. Based on the colour of nodes, the United States, the United Kingdom, Sweden, Canada (blue nodes) were the traditional countries in the research area. On the other hand, Turkey, Egypt, Nepal, United Arab Emirates, Chile, Spain, New Caledonia, Denmark, Lithuania, Latvia (yellow nodes) were the new countries of the CSP research community. In the new group, Denmark was the most published country (eight documents), and New Caledonia and the United Arab Emirates were the latest countries that had a publication in 2020 .

\section{Figure 2}

Country Collaborations Overtime Based on Authors' Affiliation (type of analysis: co-author, threshold: at least a document each country)

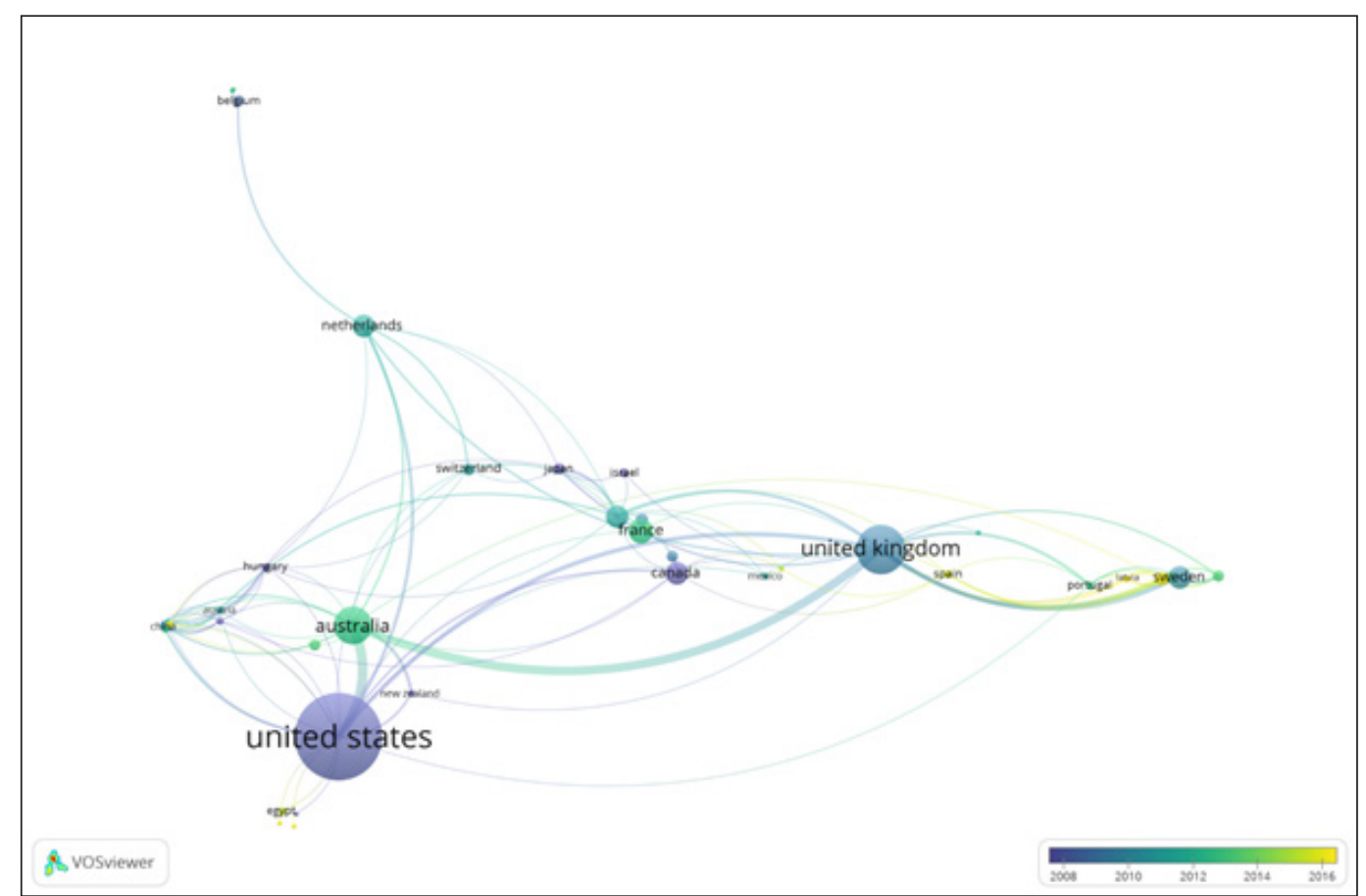

Note: A node illustrated a country. The size of a node showed a positive ratio to the number of publications of a country. Colour of a node shows the average published time of all documents of a country. A link between two nodes pointed out a collaboration of authors between two countries. The strength of a link showed a positive number of collaboration of authors between two countries.

$\mid$\begin{tabular}{l} 
PROBLEMS \\
OF EDUCATION \\
IN THE 21 $1^{\text {st }}$ CENTURY \\
Vol. 79, No. 4, 2021 \\
\hline 615
\end{tabular} 
Ly Thi Bac LA, Nga Thi Thu NGUYEN, Anh Thi Thuy TRUONG, Thu-Giang TRAN, The-Thang NGUYEN. A bibliometric analysis of cohesive speech research of preschoolers from 1970 to 2020

IN THE $21^{\text {st }}$ CENTURY Vol. 79 , No. 4,2021 616

\section{The Greatest Relevant Authors in CSP Research and Their Interests}

The top 20 authors based on the number of documents and the number of citations were detailed in Table 1. Each author in the list had at least three documents in the CSP area. Anette Lohmander was the first ranking based on the number of publications with 11 documents and 208 citations. Following were Mark Onslow (ranking \#2, 7 documents, 311 citations), Ann Packman (ranking \#3, 7 documents, 310 citations), and they had the same affiliations, The University of Sydney, Australia. Based on the number of citations, Judith E. C. Lieu in St. Louis University School of Public Health, US, had the most citations in the CSP field. The top three authors in Table 1 had the citations' ranking as \#16 (Anette Lohmander), \#2 (Mark Onslow) and \#3 (Ann Packman).

Table 1

Top 20 Authors Base on the Number of SCP Publications between 1970 and 2020

\begin{tabular}{|c|c|c|c|c|c|c|c|}
\hline ID & Author & Affiliation & h_index & NP & $\mathrm{TC}$ & $\begin{array}{c}\mathrm{TC} \\
\text { ranking }\end{array}$ & PY \\
\hline 1 & Anette Lohmander & $\begin{array}{l}\text { Karolinska Institute and Karolinska } \\
\text { University Hospital, Sweden }\end{array}$ & 7 & 11 & 208 & 16 & 2002 \\
\hline 2 & Mark Onslow & The University of Sydney, Australia & 6 & 7 & 311 & 2 & 2003 \\
\hline 3 & Ann Packman & The University of Sydney, Australia & 6 & 7 & 310 & 3 & 2003 \\
\hline 4 & Mark Johns & $\begin{array}{l}\text { The University of Queensland, } \\
\text { Australia }\end{array}$ & 5 & 5 & 279 & 8 & 2003 \\
\hline 5 & Jill Nyberg & $\begin{array}{l}\text { Karolinska University Hospital, } \\
\text { Sweden }\end{array}$ & 4 & 5 & 89 & 70 & 2014 \\
\hline 6 & Christina Persson & University Hospital, Sweden & 3 & 5 & 77 & 95 & 2002 \\
\hline 7 & Elisabeth Willadsen & University of Copenhagen, Denmark & 2 & 5 & 60 & 225 & 2017 \\
\hline 8 & $\begin{array}{c}\text { Fernanda Dreux } \\
\text { Miranda Fernandes }\end{array}$ & Universidade de São Paulo, Brazil & 2 & 5 & 16 & 729 & 2007 \\
\hline 9 & Judith E. C. Lieu & $\begin{array}{c}\text { St. Louis University School of Public } \\
\text { Health, US }\end{array}$ & 4 & 4 & 370 & 1 & 2010 \\
\hline 10 & Andrew Pickles & Kings College London, UK & 4 & 4 & 305 & 4 & 2012 \\
\hline 11 & Tony Charman & Kings College London, UK & 4 & 4 & 300 & 5 & 2011 \\
\hline 12 & Howlin P & Kings College London, UK & 4 & 4 & 300 & 5 & 2011 \\
\hline 13 & Barbara A. Lewis & $\begin{array}{c}\text { Case Western Reserve University, } \\
\text { US }\end{array}$ & 4 & 4 & 232 & 13 & 2000 \\
\hline 14 & Natalie Loundon & $\begin{array}{l}\text { Hôpital Necker-Enfants-Malades, } \\
\text { France }\end{array}$ & 3 & 4 & 89 & 71 & 2000 \\
\hline 15 & $\begin{array}{l}\text { Siena M. Goorhuis- } \\
\text { Brouwer }\end{array}$ & $\begin{array}{l}\text { University of Groningen, The } \\
\text { Netherlands }\end{array}$ & 3 & 4 & 45 & 326 & 2002 \\
\hline 16 & $\begin{array}{l}\text { Bowornsilp } \\
\text { Chowchuen }\end{array}$ & Khon Kaen University, Thailand & 3 & 4 & 13 & 820 & 2011 \\
\hline 17 & Benjamas Prathanee & Khon Kaen University, Thailand & 1 & 4 & 7 & 1023 & 2014 \\
\hline 18 & Márcia Keske-Soares & $\begin{array}{c}\text { Federal University of Santa Maria, } \\
\text { Brazil }\end{array}$ & 1 & 4 & 4 & 1256 & 2012 \\
\hline 19 & Barbara Dodd & City University, UK & 3 & 3 & 265 & 9 & 2004 \\
\hline 20 & Vicky Slonims & $\begin{array}{c}\text { Guys and St Thomas University } \\
\text { NHS Trust, UK }\end{array}$ & 3 & 3 & 222 & 15 & 2012 \\
\hline
\end{tabular}


Ly Thi Bac LA, Nga Thi Thu NGUYEN, Anh Thi Thuy TRUONG, Thu-Giang TRAN, The-Thang NGUYEN. A bibliometric analysis of cohesive speech research of preschoolers from 1970 to 2020

Note: NP: number of publications; TC: total citations; TC ranking: ranking of author based on number of citations; PY: the published year of the first document of the author

The science mapping of author relationships was shown in Figure 3, whose connections were determined based on the authors' co-citations analysis. Three hundred nine authors were divided into six clusters. Four dominant ones, at least 50 authors, were figured out, including the red cluster (93 nodes), the green cluster ( 65 nodes), the blue cluster (64 nodes) and the orange cluster (50 nodes). Two smaller clusters were the purple one (21 nodes) and the grey one (16 nodes). Based on the research of authors, the main interest of each cluster was explored. The red cluster, which had 93 authors, 164 links and 1,915 link strength, focused on "language development" for pre-schoolers.

\section{Figure 3}

Author Relationships Base on the Authors' Co-citation Analysis (number of the author: 309; co-citation threshold: at least ten times)

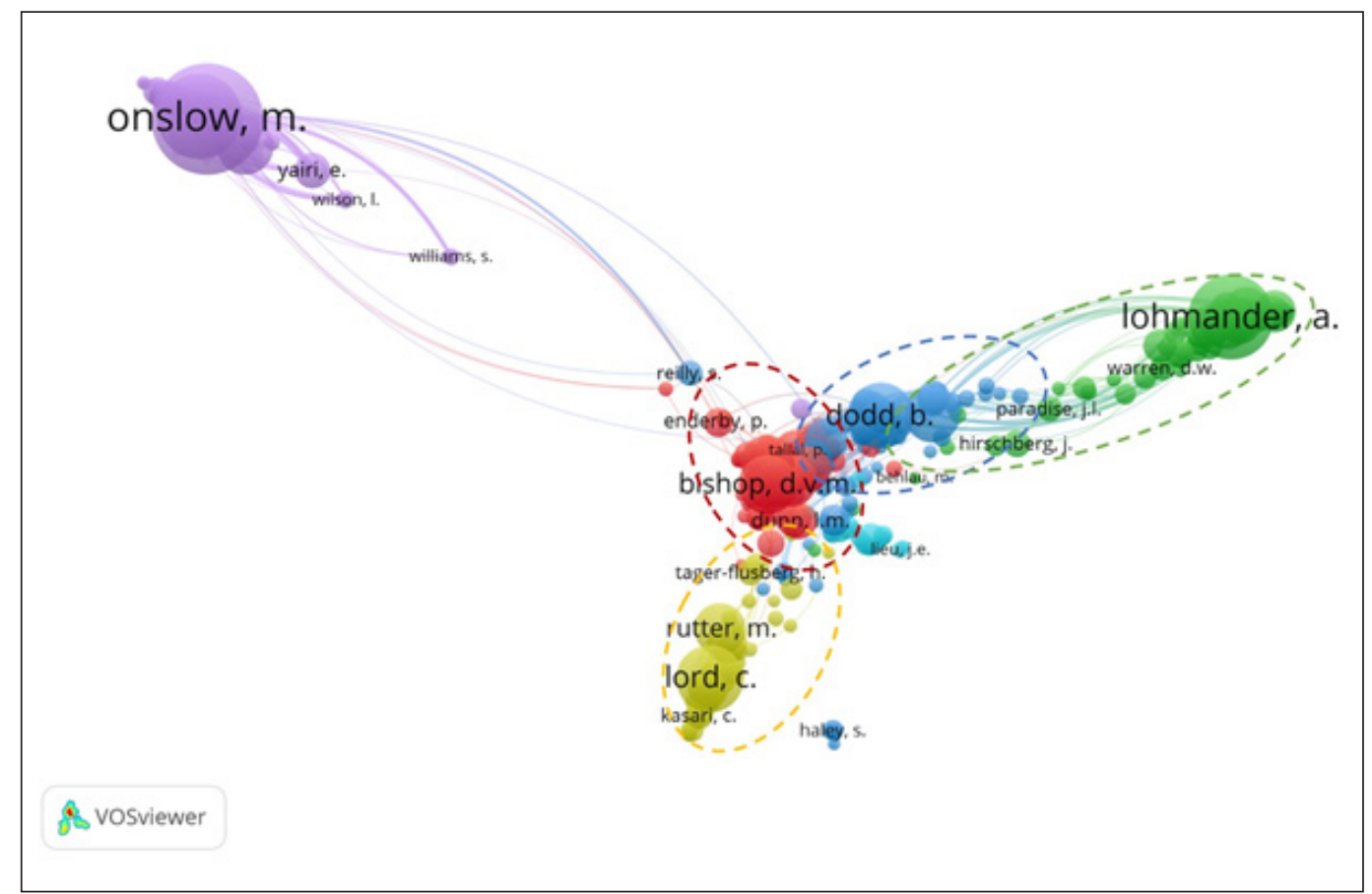

Note: A node illustrated an author. The size of a node showed a positive ratio of the number of citations of an author. A link between two nodes pointed out their collaboration. The strength of a link showed a positive number of collaboration of authors.

\section{The Most Relevant Documents and Topics in the CSP Knowledge Base}

A list of 20 publications based on the number of citations within the CSP field was detailed in Table 2. According to its data, (Kingston et al., 2003) was at the first ranking with eight local citations and 72 global citations. The following were (Lohmander et al., 2012) (\#2, $6,33)$ and (Jones et al., 2005) (\#3, 5, 140). A ratio value between local citation and global citation of a publication determined its effect on its knowledge base and others. Therefore, all publications in Table 2 had less effect on the CSP field than their effect on others. Based on the documents' source, their scopes focused on Language and Linguistics, Speech and Hearing, Psychology, and Medicine, which closely related to this research area. 
Ly Thi Bac LA, Nga Thi Thu NGUYEN, Anh Thi Thuy TRUONG, Thu-Giang TRAN, The-Thang NGUYEN. A bibliometric analysis of cohesive speech research of preschoolers from 1970 to 2020

OF EDUCATION IN THE $21^{\text {st }}$ CENTURY Vol. 79, No. 4, 2021
Table 2

Top 20 Most Relevant Documents in the CSP between 1970 and 2020

\begin{tabular}{|c|c|c|c|c|c|c|c|}
\hline ID & Title & $\begin{array}{l}\text { 1st author, } \\
\text { published } \\
\text { year }\end{array}$ & Source & $\begin{array}{l}\text { Scope of } \\
\text { source }\end{array}$ & LC & GC & $\begin{array}{c}\text { LC/GC } \\
\text { ratio }\end{array}$ \\
\hline 1 & $\begin{array}{l}\text { Predicting treatment } \\
\text { time with the Lidcombe } \\
\text { program: Replication and } \\
\text { meta-analysis }\end{array}$ & $\begin{array}{l}\text { Kingston M, } \\
2003\end{array}$ & $\begin{array}{l}\text { International Journal } \\
\text { of Language \& } \\
\text { Communication } \\
\text { Disorders }\end{array}$ & $\begin{array}{l}\text { Language and } \\
\text { Linguistics; } \\
\text { Speech and } \\
\text { Hearing; }\end{array}$ & 8 & 72 & 0.111 \\
\hline 2 & $\begin{array}{l}\text { Long-term, longitudinal } \\
\text { follow-up of individuals } \\
\text { with unilateral cleft lip } \\
\text { and palate after the } \\
\text { Gothenburg primary } \\
\text { early veloplasty and } \\
\text { delayed hard palate } \\
\text { closure protocol: Speech } \\
\text { outcome }\end{array}$ & $\begin{array}{l}\text { Lohmander A, } \\
2012\end{array}$ & $\begin{array}{l}\text { The Cleft Palate- } \\
\text { Craniofacial Journal }\end{array}$ & $\begin{array}{l}\text { Medicine; } \\
\text { Dentistry }\end{array}$ & 6 & 33 & 0.182 \\
\hline 3 & $\begin{array}{l}\text { Randomized controlled } \\
\text { trial of the Lidcombe } \\
\text { programme of early } \\
\text { stuttering intervention }\end{array}$ & Jones M, 2005 & $\begin{array}{l}\text { British Medical } \\
\text { Journal }\end{array}$ & Medicine & 5 & 140 & 0.036 \\
\hline 4 & $\begin{array}{l}\text { Intervention for children } \\
\text { with severe speech } \\
\text { disorder: A comparison of } \\
\text { two approaches }\end{array}$ & $\begin{array}{l}\text { Crosbie S, } \\
2005\end{array}$ & $\begin{array}{l}\text { International Journal } \\
\text { of Language and } \\
\text { Communication } \\
\text { Disorders }\end{array}$ & $\begin{array}{l}\text { Language and } \\
\text { Linguistics; } \\
\text { Speech and } \\
\text { Hearing; }\end{array}$ & 5 & 101 & 0.05 \\
\hline 5 & $\begin{array}{l}\text { Speech production of } \\
\text { pre-schoolers with cleft } \\
\text { palate }\end{array}$ & $\begin{array}{l}\text { Hardin-Jones } \\
\text { MA, } 2005\end{array}$ & $\begin{array}{l}\text { Cleft Palate- } \\
\text { Craniofacial Journal }\end{array}$ & $\begin{array}{l}\text { Medicine; } \\
\text { Dentistry }\end{array}$ & 4 & 88 & 0.045 \\
\hline 6 & $\begin{array}{l}\text { A comparative trial } \\
\text { of two modalities of } \\
\text { speech intervention for } \\
\text { compensatory articulation } \\
\text { in cleft palate children, } \\
\text { phonologic approach } \\
\text { versus articulatory } \\
\text { approach }\end{array}$ & $\begin{array}{l}\text { Pamplona } \\
\text { MC, } 1999\end{array}$ & $\begin{array}{l}\text { International } \\
\text { Journal of Pediatric } \\
\text { Otorhinolaryngology }\end{array}$ & Medicine & 4 & 59 & 0.068 \\
\hline 7 & $\begin{array}{l}\text { Development of } \\
\text { articulation before } \\
\text { delayed hard-palate } \\
\text { closure in children with } \\
\text { cleft palate: A cross- } \\
\text { sectional study }\end{array}$ & $\begin{array}{l}\text { Noordhoff MS, } \\
1987\end{array}$ & $\begin{array}{l}\text { Plastic and } \\
\text { Reconstructive } \\
\text { Surgery }\end{array}$ & Medicine & 4 & 44 & 0.091 \\
\hline 8 & $\begin{array}{l}\text { Velopharyngeal function } \\
\text { from the age of three to } \\
\text { eight years in cleft palate } \\
\text { patients }\end{array}$ & $\begin{array}{l}\text { Pulkkinen J, } \\
2001\end{array}$ & $\begin{array}{l}\text { Folia Phoniatrica et } \\
\text { Logopaedica }\end{array}$ & $\begin{array}{l}\text { Language and } \\
\text { Linguistics; } \\
\text { Speech and } \\
\text { Hearing; } \\
\text { Nursing }\end{array}$ & 4 & 27 & 0.148 \\
\hline 9 & $\begin{array}{l}\text { Unilateral hearing loss } \\
\text { is associated with worse } \\
\text { speech-language scores } \\
\text { in children }\end{array}$ & $\begin{array}{l}\text { Lieu JEC, } \\
2010\end{array}$ & Pediatrics & Medicine & 3 & 174 & 0.017 \\
\hline
\end{tabular}


Ly Thi Bac LA, Nga Thi Thu NGUYEN, Anh Thi Thuy TRUONG, Thu-Giang TRAN, The-Thang NGUYEN. A bibliometric analysis of cohesive speech research of preschoolers from 1970 to 2020

\begin{tabular}{|c|c|c|c|c|c|c|c|c|}
\hline & & & & & & & & $\begin{array}{l}\text { PROBLEMS } \\
\text { OF EDUCATION } \\
\text { IN THE } 21^{\text {st }} \text { CENTURY } \\
\text { Vol. } 79, \text { No. 4, } 2021\end{array}$ \\
\hline 10 & $\begin{array}{l}\text { Children with speech } \\
\text { and language disability: } \\
\text { Caseload characteristics }\end{array}$ & $\begin{array}{l}\text { Broomfield J, } \\
2004\end{array}$ & $\begin{array}{l}\text { International Journal } \\
\text { of Language and } \\
\text { Communication } \\
\text { Disorders }\end{array}$ & $\begin{array}{l}\text { Language and } \\
\text { Linguistics; } \\
\text { Speech and } \\
\text { Hearing; }\end{array}$ & 3 & 129 & 0.023 & 619 \\
\hline 11 & $\begin{array}{l}\text { Longitudinal study of } \\
\text { children with unilateral } \\
\text { hearing loss }\end{array}$ & $\begin{array}{l}\text { Lieu JEC, } \\
2012\end{array}$ & Laryngoscope & Medicine & 3 & 119 & 0.025 & \\
\hline 12 & $\begin{array}{l}\text { Voice disorders in } \\
\text { children }\end{array}$ & $\begin{array}{l}\text { Hirschberg J, } \\
1995\end{array}$ & $\begin{array}{l}\text { International } \\
\text { Journal of Pediatric } \\
\text { Otorhinolaryngology }\end{array}$ & Medicine & 3 & 77 & 0.039 & \\
\hline 13 & $\begin{array}{l}\text { Management of } \\
\text { dysphonia in children }\end{array}$ & $\begin{array}{l}\text { Connelly A, } \\
2009\end{array}$ & $\begin{array}{l}\text { Journal of } \\
\text { Laryngology and } \\
\text { Otology }\end{array}$ & Medicine & 3 & 26 & 0.115 & \\
\hline 14 & $\begin{array}{l}\text { Academic outcomes in } \\
\text { children with histories of } \\
\text { speech sound disorders }\end{array}$ & $\begin{array}{l}\text { Lewis BA, } \\
2000\end{array}$ & $\begin{array}{l}\text { Journal of } \\
\text { Communication } \\
\text { Disorders }\end{array}$ & $\begin{array}{l}\text { Language and } \\
\text { Linguistics; } \\
\text { Speech and } \\
\text { Hearing; } \\
\text { Nursing; } \\
\text { Psychology }\end{array}$ & 2 & 72 & 0.028 & \\
\hline 15 & $\begin{array}{l}\text { A randomized control trial } \\
\text { to investigate the impact } \\
\text { of the Lidcombe program } \\
\text { on early stuttering in } \\
\text { German-speaking pre- } \\
\text { schoolers }\end{array}$ & $\begin{array}{l}\text { Lattermann C, } \\
2008\end{array}$ & $\begin{array}{l}\text { Journal of Fluency } \\
\text { Disorders }\end{array}$ & $\begin{array}{l}\text { Language and } \\
\text { Linguistics; } \\
\text { Speech and } \\
\text { Hearing; } \\
\text { Nursing; } \\
\text { Psychology }\end{array}$ & 2 & 53 & 0.038 & \\
\hline 16 & $\begin{array}{l}\text { Epidemiological study } \\
\text { on vocal disorders in } \\
\text { pediatric age }\end{array}$ & $\begin{array}{l}\text { Angelillo N, } \\
2008\end{array}$ & $\begin{array}{l}\text { Journal of } \\
\text { Preventive Medicine } \\
\text { and Hygiene }\end{array}$ & Medicine & 2 & 51 & 0.039 & \\
\hline 17 & $\begin{array}{l}\text { Dimensions of early } \\
\text { speech sound disorders: } \\
\text { A factor analytic study }\end{array}$ & $\begin{array}{l}\text { Lewis BA, } \\
2006\end{array}$ & $\begin{array}{l}\text { Journal of } \\
\text { Communication } \\
\text { Disorders }\end{array}$ & $\begin{array}{l}\text { Language and } \\
\text { Linguistics; } \\
\text { Speech and } \\
\text { Hearing; } \\
\text { Nursing; } \\
\text { Psychology }\end{array}$ & 2 & 46 & 0.043 & \\
\hline
\end{tabular}

\begin{tabular}{|c|c|c|c|c|c|c|c|}
\hline 18 & $\begin{array}{l}\text { Healthcare service use } \\
\text { and costs for autism } \\
\text { spectrum disorder: A } \\
\text { comparison between } \\
\text { Medicaid and private } \\
\text { insurance }\end{array}$ & Wang L, 2013 & $\begin{array}{l}\text { Journal of Autism } \\
\text { and Developmental } \\
\text { Disorders }\end{array}$ & Psychology & 2 & 45 & 0.044 \\
\hline 19 & $\begin{array}{l}\text { Recast density and } \\
\text { acquisition of novel } \\
\text { irregular past tense verbs }\end{array}$ & $\begin{array}{l}\text { Proctor- } \\
\text { Williams K, } \\
2007\end{array}$ & $\begin{array}{l}\text { Journal of Speech, } \\
\text { Language, and } \\
\text { Hearing Research }\end{array}$ & $\begin{array}{l}\text { Language and } \\
\text { Linguistics; } \\
\text { Speech and } \\
\text { Hearing; } \\
\text { Medicine }\end{array}$ & 2 & 44 & 0.045 \\
\hline 20 & $\begin{array}{l}\text { Voice therapy in pediatric } \\
\text { functional dysphonia: A } \\
\text { prospective study }\end{array}$ & Trani M, 2007 & $\begin{array}{l}\text { International } \\
\text { Journal of Pediatric } \\
\text { Otorhinolaryngology }\end{array}$ & Medicine & 2 & 37 & 0.054 \\
\hline
\end{tabular}


Ly Thi Bac LA, Nga Thi Thu NGUYEN, Anh Thi Thuy TRUONG, Thu-Giang TRAN, The-Thang NGUYEN. A bibliometric analysis of cohesive speech research of preschoolers from 1970 to 2020

PROBLEMS

OF EDUCATION

IN THE $21^{\text {st }}$ CENTURY

Vol. 79, No. 4, 2021

The most relevant topics based on the coupling analysis of documents were represented in Figure 4. The location of a cluster in the figure determined its impact and centrality in the CSP knowledge base. In this field, "speech pathology outcomes" was the most significant theme, which had a high impact and a high centrality. The most important documents of this theme were Kingston et al. (2003) and Lieu et al. (2010). Another important theme was "language intervention and language development" for pre-schoolers. The publications that represented this theme were Broomfield \& Dodd (2004); Lewis et al. (2006); Lohmander et al. (2012). On the other hand, two less important themes that had CSP communication interest were "healthcare service" and "speech therapy". Wang et al. (2013) and Murray et al. (2012) were the most relevant publication of these topics.

\section{Figure 4}

Most Relevant Topics in CSP area Bases on the Coupling Analysis of Documents (each cluster have at least 30 citations)

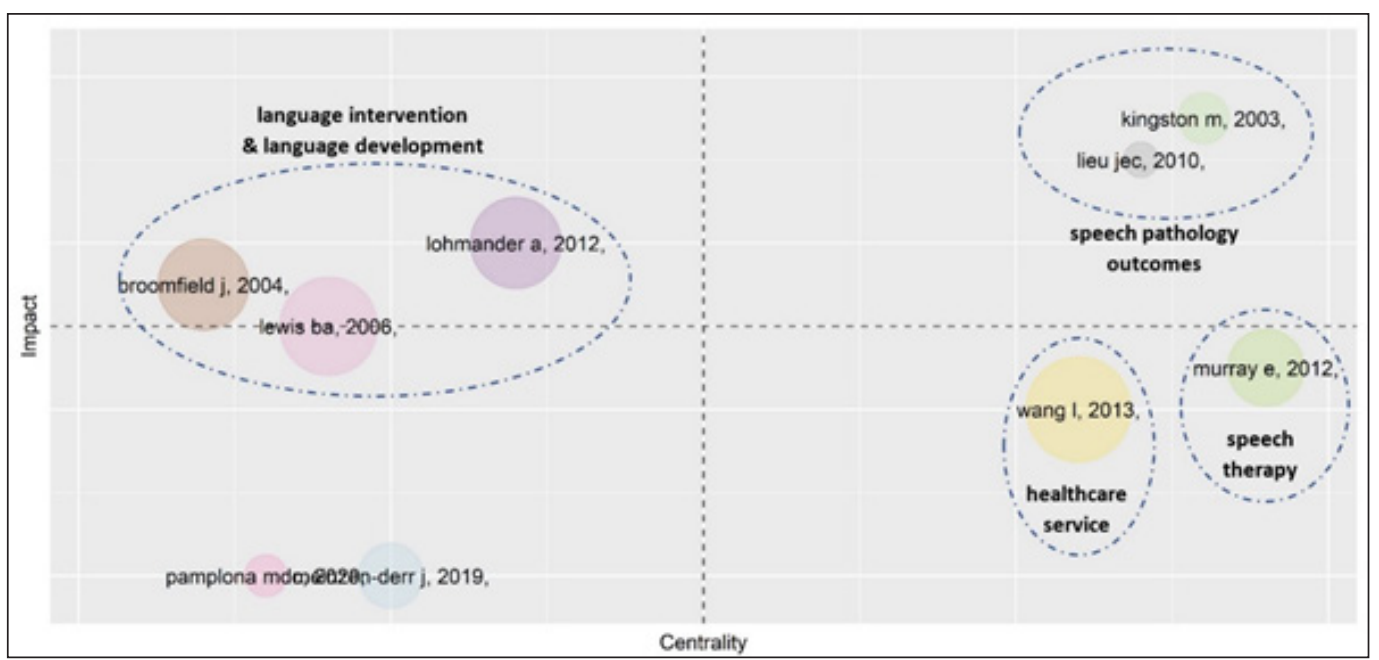

The Latest Topics in Recent Years in the CSP Knowledge Base

All the relationships among authors' keywords were demonstrated in Figure 5. The science mapping represented 171 authors' keywords, 778 links and 1,008 link strength. Based on the size of nodes, the most relevant keywords were children (ranking \#1, frequency: 53, total link strength: 139), cleft palate (\#2, 25, 59), speech therapy (\#3, 21, 48), intervention (\#4, 21, $58)$, and speech $(\# 5,19,61)$. These keywords were the traditional ones. Besides, according to the colour of nodes, some keywords appeared in the SCP area in recent years, which connected to the traditional one as the expanse of the research topics. They were "autism spectrum disorder" (occurrence: 12 times, total link strength: 26), "randomized controlled trial" $(3,10)$, "primary palatal repair" $(3,10)$, "hard of hearing" $(2,11)$, vocabulary $(2,9)$, "telepractice" $(2$, $7)$, cross-linguistic $(2,7)$, "consonant proficiency" $(2,6)$, "executive function" $(2,5)$. Within this knowledge base, there was a research related to the COVID-19 pandemic. Pamplona and Ysunza (2020) showed that telepractice could be a safe tool to improve the speech performance of children with cleft palate. They also recommended alternate modes of health care services should be studied and adapted in this context. Besides, Meinzen-Derr et al. (2019) had a pilot study that showed a significant increase in deaf/hard of hearing children' mean length of utterance, the number of words spoken. In another pilot study, Padmanabha et al. (2019) proved home-based sensory interventions in autism spectrum disorder children are the feasible approach for developing countries. 
Ly Thi Bac LA, Nga Thi Thu NGUYEN, Anh Thi Thuy TRUONG, Thu-Giang TRAN, The-Thang NGUYEN. A bibliometric analysis of cohesive speech research of preschoolers from 1970 to 2020

\section{Figure 5}

Science Mapping of Keywords Base on the Co-occurrence Analysis of Authors' Keywords

PROBLEMS

OF EDUCATION

IN THE $21^{\text {st }}$ CENTURY

Vol. 79, No. 4, 2021 (number of keywords: 171, frequency of keyword: at least two times)

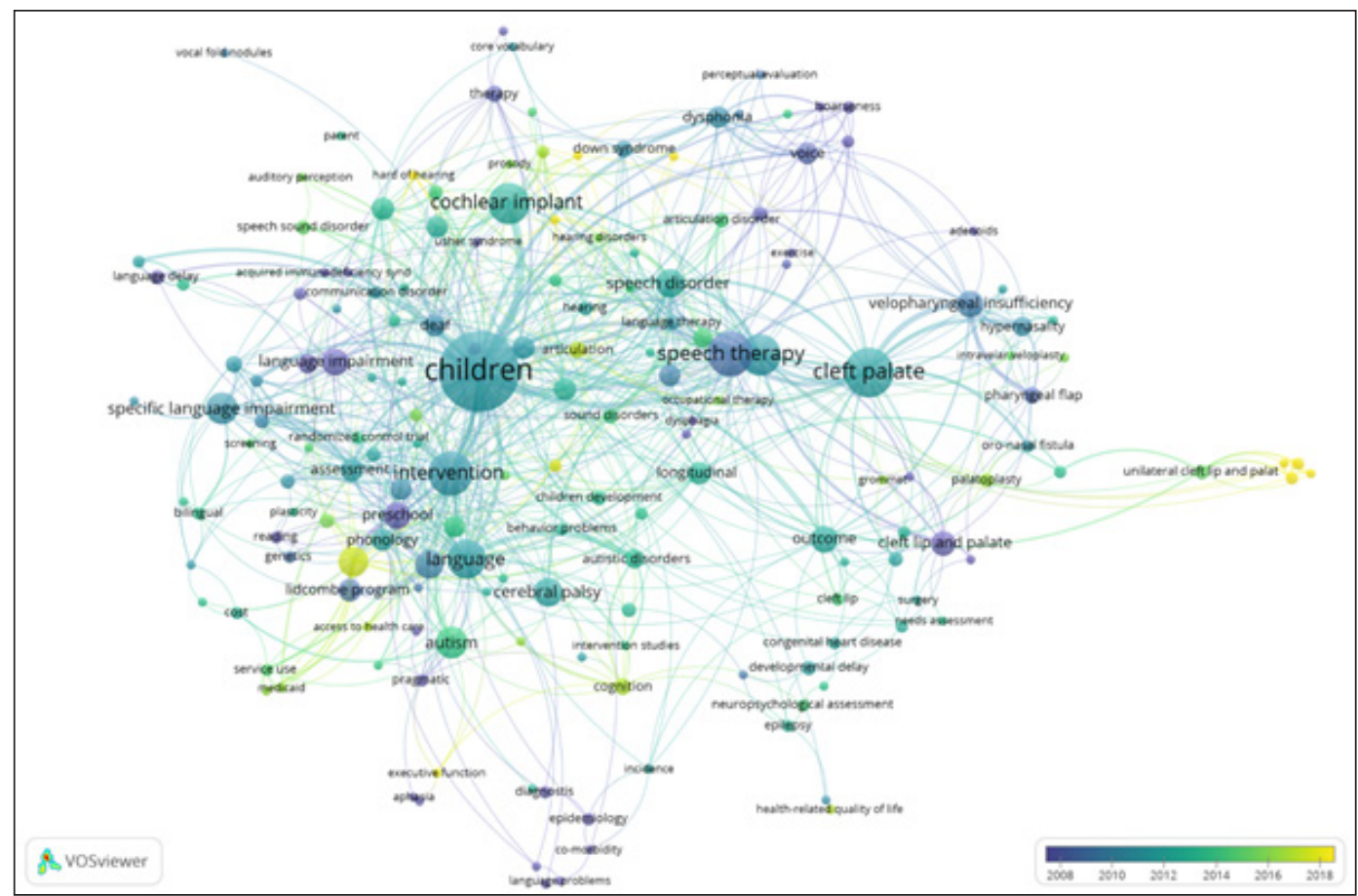

Note: A node illustrated an author's keyword. The size of a node showed a positive ratio of the number of publications of a keyword. Colour of a node showed the average published time of all documents of a keyword. A link between two nodes pointed out a co-occurrence of keywords. The strength of a link showed a positive number of co-occurrence of keywords.

\section{Discussion}

Based on the database that was used in this research, it seems that the total publications have not much in quantitative terms. This can be possible that most of these documents were published in advanced countries or Western nations, and they are all in English, and the total articles can be much more if they are collected from other areas and countries in the world. This shares the same tendency with the links among countries, though some developing countries and the countries far from Western have partially contributed to this research sector in recent years. The most interesting finding was that there is no country in Asia published in this discipline except Nepal. As mentioned in the introduction, there are possibly many more themes of this research topic published in other languages, and Russia is an example.

The authors have had the greatest relevance in CSP research, and what they are interested in are quite diverse. For example, Snowling et al. (2006) re-evaluated 71 young people who had a preschool history of speech language impairment; (Law et al., 2011) concerned communication skills of primary school-aged children who were raised in pronounced social disadvantage areas. The green clusters (65 authors; 100 links; 6,161 link strength) related to "speech pathology outcomes". According to Klintö et al. (2011), word naming is the most important speech material for speech judgement of children with cleft palate. Besides, del Carmen Pamplona and Ysunza (2020) pointed out the telepractice of speech and language pathology could improve the 
Ly Thi Bac LA, Nga Thi Thu NGUYEN, Anh Thi Thuy TRUONG, Thu-Giang TRAN, The-Thang NGUYEN. A bibliometric analysis of cohesive speech research of preschoolers from 1970 to 2020

PROBLEMS

OF EDUCATION IN THE $21^{\text {st }}$ CENTURY Vol. 79, No. 4, 2021

622

speech performance of children with cleft palate. The blue cluster (64 authors; 304 links; 3,160 link strength) represented "speech therapy" issues. Thomas-Stonell et al. (2013), authors of this one, designed a questionnaire to measure the changes in communication skills. Moreover, Sices et al. (2007) determined the link between speech disorders and early literacy skills based on the Comorbid Language Impairment of preschool-age children. The last dominant cluster was orange one (50 authors; 56 links; 345 link strength), namely the "language intervention". Following Homøe et al. (2013), the authors suggested using cochlear implants to increase the efficiency of treatment and rehabilitation for children in Greenland.

As can be seen from the documents mentioned above, documents and topics have had the greatest relevance in the CSP knowledge base, are conducted by mixed areas including language, linguistics, therapy. That document "Predicting treatment time with the Lidcombe program: Replication and meta-analysis" (Kingston et al., 2003) is just one example, and the title "Intervention for children with severe speech disorder: A comparison of two approaches" (Crosbie, 2005) is another one of special education perspective. The nine documents are classified into source of medicine (Angelillo, 2008; Connelly, 2009; Jones, 2005; Lieu, 2010; Lieu, 2012; Noordhoff, 1987; Pamplona, 1999; Hirschberg, 1995; Trani, 2007), but these research studies are partly studied by health combined with special education or linguistics features. The only one document researched into economical side of insurance provided for patients with autism spectrum disorder (Wang, 2013) is grouped in the psychology discipline.

The findings of this study indicate that health issues relevant to linguistic developments of the children are of interest by most researchers (Jones et al., 2005; Kingston et al., 2003; Lohmander et al., 2012) and these problems will affect many features in the ways of cohesive speeches. Children with speech disorders mentioned in these studies need certain types of therapy to make their speeches accurate and consistent. Whilst most research studies have been carried out on health sectors or therapies that are frequently used to intervene in language development for children regarding health assistance, and there have been few empirical investigations into linguistic ability of the scope that could help children to learn and other interactions in the school. This finding was unexpected and suggested that the database should be added more documents that will make the research domain become a better picture of researching into the cohesive speech of pre-schoolers.

\section{Conclusions}

Over the five decades, the publications of CSP have experienced an upward trend, especially the numbers of documents that have dramatically come to light in the last decade and reached their highest in the years of 2012 and 2014. This article also provides an exciting opportunity to advance the knowledge of how important language development is to preschoolers both in cognitive development and in establishing the first important functions of expressing how these children think and say, what they think before schooling. More importantly, the findings provide some suggestions and implications or some actions that could be taken by educators/ teachers and parents to help children be who they are in their ages.

CSP cannot be regarded as a totally separate discipline or research these days because everything is connected to something else, and cohesive speech is not exceptional. Moreover, cohesive speech with both positive sides can be seen and studied in many scientific fields. This is why publications mentioned in this paper should be seen in the different perspectives of different domains or interdisciplinary and multidisciplinary. Besides, in view of all that has been mentioned so far, one may suppose that the information referred to in this research is limited by a database and in English only. These documents, therefore, are not represented in all the publications of the field in the scientific community in the global. 
Ly Thi Bac LA, Nga Thi Thu NGUYEN, Anh Thi Thuy TRUONG, Thu-Giang TRAN, The-Thang NGUYEN. A bibliometric analysis of cohesive speech research of preschoolers from 1970 to 2020

Above findings have a number of important implications for futuristic practice. That is, the need for further research into language developments of pre-schoolers separately because this domain and children cognition have been proved entwined, but opposite need for many more research studies of language developments of pre-schoolers should be carried out from the perspective of interdisciplinary approaches different from conventional ways that artificial intelligence is one of the good examples. That is, they should have more joint studies in this discipline conducted by varied scholars of different countries, and research results of these studies will represent knowledge of different cultures and languages, and even by doing in this way researchers can develop a global or regional network providing favourable conditions for those who have the same research interests of CSP.

\section{Declaration of Interest}

Authors declare no competing interest.

\section{References}

Broomfield, J., \& Dodd, B. (2004). Children with speech and language disability: Caseload characteristics. International Journal of Language \& Communication Disorders, 39(3), 303 324. https://doi.org/10.1080/13682820310001625589

Egorova, U. G. (2020). Working with parents to develop coherent speech in older pre-schoolers. Izvestiya of the Samara Science Centre of the Russian Academy of Sciences. Social, Humanitarian, Medicobiological Sciences, 22(74), 21-25. https://doi.org/10.37313/2413-9645-2020-22-74-21-25

Fetscherin, M., \& Heinrich, D. (2015). Consumer brand relationships research: A bibliometric citation meta-analysis. Journal of Business Research, 68(2), 380-390. https://doi.org/10.1016/j.jbusres.2014.06.010

Hallinger, P., \& Chatpinyakoop, C. (2019). A bibliometric review of research on higher education for sustainable development, 1998-2018. Sustainability, 11(8), 2401. https://doi.org/10.3390/su11082401

Harzing, A. W., \& Alakangas, S. (2017). Microsoft Academic: Is the phoenix getting wings? Scientometrics, 110(1), 371-383. https://doi.org/10.1007/s11192-016-2185-x

Homøe, P., Andersen, T., Grøntved, A., Percy-Smith, L., \& Bille, M. (2013). Experience with cochlear implants in Greenlanders with profound hearing loss living in Greenland. International Journal of Circumpolar Health, 72(1). https://doi.org/10.3402/ijch.v72i0.20974

Jones, M., Onslow, M., Packman, A., Williams, S., Ormond, T., Schwarz, I., \& Gebski, V. (2005). Randomised controlled trial of the Lidcombe programme of early stuttering intervention. The British Medical Journal, 331(7518), 659. https://doi.org/10.1136/bmj.38520.451840.E0

Kingston, M., Huber, A., Onslow, M., Jones, M., \& Packman, A. (2003). Predicting treatment time with the Lidcombe Program: Replication and meta-analysis. International Journal of Language \& Communication Disorders, 38(2), 165-177. https://doi.org/10.1080/1368282031000062882

Klintö, K., Salameh, E.-K., Svensson, H., \& Lohmander, A. (2011). The impact of speech material on speech judgement in children with and without cleft palate. International Journal of Language \& Communication Disorders, 46(3), 348-360. https://doi.org/10.3109/13682822.2010.507615

Kuznetsova, E. (2020). Development of coherent speech in children of senior preschool age by means of project activities. Bulletin of Kemerovo State University. Series: Humanities and Social Sciences, 2020(3), 198-206. https://doi.org/10.21603/2542-1840-2020-4-3-198-206

Law, J., McBean, K., \& Rush, R. (2011). Communication skills in a population of primary school-aged children raised in an area of pronounced social disadvantage. International Journal of Language \& Communication Disorders, 46(6), 657-664. https://doi.org/10.1111/j.1460-6984.2011.00036.x

Lewis, B. A., Freebairn, L. A., Hansen, A. J., Stein, C. M., Shriberg, L. D., Iyengar, S. K., \& Taylor, H. G. (2006). Dimensions of early speech sound disorders: A factor analytic study. Journal of Communication Disorders, 39(2), 139-157. https://doi.org/10.1016/j.jcomdis.2005.11.003

\begin{tabular}{|l} 
PROBLEMS \\
OF EDUCATION \\
IN THE 21 $1^{\text {st }}$ CENTURY \\
Vol. 79, No. 4, 2021 \\
\hline 623
\end{tabular} 
Ly Thi Bac LA, Nga Thi Thu NGUYEN, Anh Thi Thuy TRUONG, Thu-Giang TRAN, The-Thang NGUYEN. A bibliometric analysis of cohesive speech research of preschoolers from 1970 to 2020

PROBLEMS

OF EDUCATION IN THE $21^{\text {st }}$ CENTURY Vol. 79, No. 4, 2021

624

Lieu, J. E. C., Tye-Murray, N., Karzon, R. K., \& Piccirillo, J. F. (2010). Unilateral hearing loss is associated with worse speech-language scores in children. Pediatrics, 125(6), e1348-e1355. https://doi.org/10.1542/peds.2009-2448

Lohmander, A., Friede, H., \& Lilja, J. (2012). Long-term, longitudinal follow-up of individuals with unilateral cleft lip and palate after the Gothenburg primary early veloplasty and delayed hard palate closure protocol: Speech outcome. The Cleft Palate-Craniofacial Journal, 49(6), 657-671. https://doi.org/10.1597/11-085

Madani, F., \& Weber, C. (2016). The evolution of patent mining: Applying bibliometrics analysis and keyword network analysis. World Patent Information, 46, 32-48. https://doi.org/10.1016/j.wpi.2016.05.008

Marti Parreño, J., Méndez Ibáñez, E., \& Alonso Arroyo, A. (2016). The use of gamification in education: A bibliometric and text mining analysis. Journal of Computer Assisted Learning, 32, 663- 676. https://doi.org/10.1111/jcal.12161

Meinzen-Derr, J., Sheldon, R. M., Henry, S., Grether, S. M., Smith, L. E., Mays, L., Riddle, I., Altaye, M., \& Wiley, S. (2019). Enhancing language in children who are deaf/hard-of-hearing using augmentative and alternative communication technology strategies. International Journal of Pediatric Otorhinolaryngology, 125, 23-31. https://doi.org/10.1016/j.ijporl.2019.06.015

Murray, E., McCabe, P., \& Ballard, K. J. (2012). A comparison of two treatments for childhood apraxia of speech: Methods and treatment protocol for a parallel group randomized control trial. BMC Pediatrics, 12(1). http://doi.org/10.1186/1471-2431-12-112

Padmanabha, H., Singhi, P., Sahu, J. K., \& Malhi, P. (2019). Home-based sensory interventions in children with autism spectrum disorder: A randomized controlled trial. The Indian Journal of Pediatrics, 86(1), 18-25. https://doi.org/10.1007/s12098-018-2747-4

Pamplona, M., \& Ysunza, P. A. (2020). Speech pathology telepractice for children with cleft palate in the times of COVID-19 pandemic. International Journal of Pediatric Otorhinolaryngology, 138, Article 110318. https://doi.org/10.1016/j.ijporl.2020.110318

Pham, H. H., Dong, T. K. T., Vuong, Q. H. et al. (2021). A bibliometric review of research on international student mobilities in Asia with Scopus dataset between 1984 and 2019. Scientometrics, 126, 52015224. https://doi.org/10.1007/s11192-021-03965-4

Prathanee, B., Pumnum, T., Yoodee, P., \& Makarabhirom, K. (2020). Speech therapy model for patients with cleft palate in Lao People's Democratic Republic: Lack of speech services. International Journal of Pediatric Otorhinolaryngology, 138, Article 110366. https://doi.org/10.1016/j.ijporl.2020.110366

Sices, L., Taylor, H. G., Freebairn, L., Hansen, A., \& Lewis, B. (2007). Relationship between speechsound disorders and early literacy skills in preschool-age children: Impact of comorbid language impairment. Journal of Developmental and Behavioral Pediatrics, 28(6), 438. https://doi.org/10.1097/dbp.0b013e31811ff8ca

Simkin, M., \& Gelikhova, K. (2019). Formation of coherent speech in senior preschoolers with the Third Degree Alalia. Bulletin of Kemerovo State University. Series: Humanities and Social Sciences, 2019(4), 333-340. https://doi.org/10.21603/2542-1840-2019-3-4-333-340

Small, H. (1999). Visualizing science by citation mapping. Journal of the American Society for Information Science, 50(9), 799-813. https://doi.org/10.1002/(SICI)1097-4571(1999)50:9<799::AIDASI9>3.0.CO;2-G

Snowling, M. J., Bishop, D. V. M., Stothard, S. E., Chipchase, B., \& Kaplan, C. (2006). Psychosocial outcomes at 15 years of children with a preschool history of speechlanguage impairment. Journal of Child Psychology and Psychiatry, 47(8), 759-765. https://doi.org/10.1111/j.1469-7610.2006.01631.x

Thomas-Stonell, N., Oddson, B., Robertson, B., \& Rosenbaum, P. (2013). Validation of the focus on the outcomes of communication under six outcome measures. Developmental Medicine \& Child Neurology, 55(6), 546-552. https://doi.org/10.1111/dmcn.12123

Trevoho, I., \& Zadorozhnyy, V. (2020). Spilna pidgotovka geodezistiv vid bakalavra do doktora filosofii v universitetah Ukraïni ta Nimechchini [Joint studies of surveyors from bachelor to doctor of philosophy at universities of Ukraine and Germany]. Офіційна хроніка, освіта, наукова, виробнича та громадська діяльність, I(39), 27-30. https://doi.org/10.33841/1819-1339-1-39-05 
Ly Thi Bac LA, Nga Thi Thu NGUYEN, Anh Thi Thuy TRUONG, Thu-Giang TRAN, The-Thang NGUYEN. A bibliometric analysis of cohesive speech research of preschoolers from 1970 to 2020

PROBLEMS

OF EDUCATION

IN THE $21^{\text {st }}$ CENTURY

Vol. 79, No. 4, 2021

Wang, L., Mandell, D. S., Lawer, L., Cidav, Z., \& Leslie, D. L. (2013). Healthcare service use and costs for autism spectrum disorder: A comparison between Medicaid and private insurance. Journal of Autism and Developmental Disorders, 43(5), 1057-1064. https://doi.org/10.1007/s10803-012-1649-y

Zupic, I., \& Čater, T. (2015). Bibliometric methods in management and organization. Organizational Research Methods, 18(3), 429-472. https://doi.org/10.1177/1094428114562629

Received: May 05, 2021

Accepted: July 30, 2021

Cite as: La, L. T. B., Nguyen, N. T. T., Truong, A. T. T., Tran, T. G., \& Nguyen, T. T. (2021). A bibliometric analysis of cohesive speech research of preschoolers from 1970 to 2020. Problems of Education in the 21 $1^{\text {st }}$ Century, 79(4), 611-625. https://doi.org/10.33225/pec/21.79.611

\begin{tabular}{|c|c|}
\hline Ly Thi Bac La & $\begin{array}{l}\text { PhD, Associate Professor, Senior Lecturer, Hanoi National University of } \\
\text { Education, } 136 \text { Xuan Thuy road, Cau Giay district, Hanoi, Vietnam. } \\
\text { E-mail: lyltb@hnue.edu.vn }\end{array}$ \\
\hline Nga Thi Thu Nguyen & $\begin{array}{l}\text { PhD, Senior Lecturer, Hanoi Metropolitan University, Vietnam. } \\
\text { E-mail: nttnga@daihocthudo.edu.vn }\end{array}$ \\
\hline Anh Thi Thuy Truong & $\begin{array}{l}\text { MA, Lecturer, Thai Nguyen University of Education, Vietnam. } \\
\text { E-mail: anhttt@tnue.edu.vn }\end{array}$ \\
\hline $\begin{array}{l}\text { Thu-Giang Tran } \\
\text { (Corresponding author) }\end{array}$ & $\begin{array}{l}\text { MA, Researcher, The Vietnam National Institute of Educational Sciences, } \\
\text { Vietnam. } \\
\text { E-mail: giangtt@vnies.edu.vn }\end{array}$ \\
\hline The-Thang Nguyen & $\begin{array}{l}\text { PhD, Senior Researcher, The Vietnam National Institute of Educational Sciences, } \\
\text { Vietnam. } \\
\text { E-mail: thangvcl@gmail.com } \\
\text { ORCID: https://orcid.org/0000-0002-3998-0099 }\end{array}$ \\
\hline
\end{tabular}

